\title{
Genetic Variability Studies among Yield and Its Contributing Traits in Mustard (Brassica napus L.)
}

\author{
Md Abdur Rauf, Md Abdur Rahim*
}

Department of Genetics and Plant Breeding, Faculty of Agriculture, Sher-e-Bangla Agricultural University, Bangladesh

Copyright $\mathrm{C} 2018$ by authors, all rights reserved. Authors agree that this article remains permanently open access under the terms of the Creative Commons Attribution License 4.0 International License

\begin{abstract}
Mustard (Brassica napus) belongs to the Brassiacaceae family and is the major edible oil producing crop of Bangladesh. The country spent a huge amount of foreign currency to import edible oil, which could be minimized through enhancing and improving the existing germplasms. To do this, the genetic variability and diversity of the existing germplasm should be evaluated. Thirty-five genotypes of mustard were evaluated based on randomized complete block design with three replications. The genotypes were found significantly variable for most of the characters. Comparatively phenotypic variances were higher than the genotypic variances for most of the characters studied. The high GCV value was observed for number of seed yield per plant. Seed yield per plant exhibited the highest value of heritability followed by number of siliquae per plant while plant height exhibited the lowest value of heritability. The significant positive correlation with seed yield per plant were found in number of primary branches, siliquae length, number of seed per plant, number of seed per siliquae and thousand seed weight. Path co-efficient analysis revealed that days to maturity, plant height, number of primary branch, siliquae length, number of siliqua per plant, number of seed per siliqua, and thousand seed weight, had direct positive effect on yield per plant. Whereas, days to $50 \%$ flowering, length of main raceme and number of secondary branch had direct negative effect on yield per plant. The genotypes were classified in four clusters. The genotypes of cluster IV showed better mean performance while cluster III showed lower mean performance for important component traits including yield per plant. Considering distance and agronomic performance genotypes G23, G5, G22 and G24 might be recommended for future hybridization program.
\end{abstract}

Keywords Genetic Variability, Heritability, Correlation, Genetic Diversity, Yield, Mustard

\section{Introduction}

Mustard (Brassica napus) belongs to the genus Brassica of the family Brassiacaceae (former Crucifereae), is mainly a self-pollinating crop, although on an average 7.5 to $30 \%$ out-crossing does occur under natural field conditions [1;2]. Brassica napus, B. campestris and $B$. juncea are the three species of mustard those produce edible oil. The major mustard producing regions are China, Indian subcontinent, Canada and Northern Europe [3]. The genus Brassica has generally been divided into three groups namely- rape seed, mustard and cole crops. The rapeseed group includes the diploid Brassica napus L, rape (AACC, $2 \mathrm{n}=38$ ) while the mustard groups include species like Brassica juncea; Brassica nigra and Brassica carinata [4]. Rapeseed is a relatively young species that originated in a limited geographic region through spontaneous hybridizations between turnip rape ( $B$. rapa L., AA, $2 \mathrm{n}=20$ ) and cabbage (B. oleracea $\mathrm{L} ., \mathrm{CC}, 2 \mathrm{n}=$ 18) genotypes [5], resulting in an amphidiploid genome comprising the full chromosome complements of its two progenitors.

Globally, mustard is one of the most important oil crops of the world after soybean and groundnut [6]. Mustard oil meets the one third of edible oil requirement of the country [7]. It is not only a high energy food but also a carrier of fat soluble vitamins like A, D, E and $\mathrm{K}$ in the body and used as a condiment, salad, green manure, fodder crop, and a leaf and stem as vegetable in the various mustard growing countries.

In Bangladesh mustard occupying 2.88 million ha in 2013-14 and 3.25 million ha in 2014-15 of land and the total production was 2.81 million metric tons and 3.5 million metric tons, respectively [8]. Bangladesh has been facing acute shortage of edible oil for the last several decades. Therefore, we need to import oil and oilseeds to meet up the deficit. Our internal production can meet only about $21 \%$ of our consumption and the rest $79 \%$ is needed to import [9]. A huge amount of foreign exchange involving over 160 million US\$ is being spent every year for importing edible oils due to insufficient oil production in Bangladesh [10]. In Bangladesh the major mustard growing districts are Comilla, Tangail, Jessore, Faridpur, Pabna, Rajshahi, Dinajpur, Kushtia, Kishoregonj, Rangpur and Dhaka [11]. Although mustard is an 
important crop but the cultivation area of this crop is declining due to late harvesting of high yielding Aman rice and increased cultivation of Boro rice and on an average we are losing in an area of 104,000 hectare and production 68,000 tons of mustard and rapeseed in last ten years [11]. Average per hectare yield of mustard in our country is alarmingly low compared to the advanced countries like Germany, France, UK and Canada which producing $6.67 \mathrm{t} / \mathrm{ha}, 5.07 \mathrm{t} / \mathrm{ha}, 3.26 \mathrm{t} / \mathrm{ha}, 3.08 \mathrm{t} / \mathrm{ha}$, respectively [12].

Variety plays an important role in producing high yield of mustard because different varieties varied differently for their genotypic characters. Improved variety is the first and foremost requirement for initiation and accelerated crop production program. High yielding varieties (HYVs) can contribute to get optimum yield as well as the highest percentage of oil. The yields of these cultivars range between 1.4 to $2.1 \mathrm{t} / \mathrm{ha}$ [13].

Development of an effective breeding program depends on the existence of genetic variability for various economic characters in the gene pool. Selection is effective only when there is enough magnitude of variability in the breeding population. An understanding of precise magnitude of variability present in a population is important in formulating the most appropriate breeding technique for improvement of various characters. The estimation of character associations helps to identify the relative importance of independent characters contributing to dependent ones and suggest upon the character(s) that may be useful as indicator for one or more of other characters. On the other hands, character associations between yield components can be used as the best guide for successful yield improvement by indirect selection.
The development of an intensive breeding and improvement program needs detailed biological information and an understanding of genetic variation for yield and its components.

There must be a thorough knowledge of the existence of genetic variability, the mode of inheritance of economic characters, heritability, the kind of gene action and the relative magnitude of additive, dominance and total genotypic and phenotypic variances of the population. So in the context of the above mentioned situation, the present piece of work was undertaken to select elite genotypes to utilize as parents for future hybridization programs.

\section{Material and Methods}

\subsection{Plant Materials and Experimental Design}

Thirty-five mustard genotypes were used in this study (Table 1). The seeds were collected from the Department of Genetics and Plant Breeding, Sher-e-Bangla Agricultural University (SAU), Dhaka-1207, Bangladesh. The experiment was carried out at the SAU experimental farm following a randomized complete bock design (RCBD) with 3 replications. The unit plot was $10 \mathrm{~m}$ with 10 rows and lines to line and plant to plant distances were $30 \mathrm{~cm}$ and $10 \mathrm{~cm}$, respectively. The recommended fertilizers and cultural practiced were done to maintain a healthy crop growth. The harvesting was done separately for each genotype when $80 \%$ of plants were mature.

Table 1. List of mustard genotypes used in this study

\begin{tabular}{|c|c|c|c|c|c|}
\hline Genotype & Accession no. & Source & Genotype & Accession no. & Source \\
\hline G1 & NAP 1005 & SAU & G19 & BARI-13 & BARI \\
\hline G2 & NAP 0762 & SAU & G20 & NAP $0717-2$ & SAU \\
\hline G3 & NAP 2057 & $\mathrm{SAU}$ & G21 & NAP 1005 & $\mathrm{SAU}$ \\
\hline G4 & NAP 10012 & SAU & G22 & NAP 2037 & SAU \\
\hline G5 & NAP 9904 & SAU & G23 & NAP 206 & SAU \\
\hline G6 & NAP 10019 & SAU & G24 & NAP 2037 & SAU \\
\hline G7 & NAP 2022 & SAU & G25 & NAP 0869 & SAU \\
\hline G8 & NAP 0733-1 & SAU & G26 & NAP 10009 & SAU \\
\hline G9 & NAP 10020 & SAU & G27 & NAP 0876 & SAU \\
\hline G10 & NAP 08-04 & SAU & G28 & NAP 2001 & SAU \\
\hline G11 & NAP 248 & SAU & G29 & NAP 2013 & SAU \\
\hline G12 & NAP 0865 & SAU & G30 & NAP 0837 & SAU \\
\hline G13 & NAP 9901 & SAU & G31 & NAP 2066 & SAU \\
\hline G14 & NAP 108 & SAU & G32 & NAP 1007 & SAU \\
\hline G15 & NAP 205 & SAU & G33 & NAP 9905 & SAU \\
\hline G16 & NAP 9906 & SAU & G34 & NAP 179 & SAU \\
\hline G17 & NAP 0885 & SAU & G35 & NAP 10017 & SAU \\
\hline G18 & NAP 10014 & SAU & & & \\
\hline
\end{tabular}




\subsection{Data Collection}

The data were recorded on 15 randomly selected plants for days to $50 \%$ flowering, days to $80 \%$ maturity, plant height $(\mathrm{cm})$, length of main raceme $(\mathrm{cm})$, number of primary branches per plant, number of secondary branches per plant, number of siliquae per plant, siliquae length $(\mathrm{cm})$, number of seeds per siliqua, 1000-seed weight $(\mathrm{g})$ and seed yield per plant $(\mathrm{g})$.

\subsection{Statistical Analysis}

The data were analyzed for different components. Phenotypic and genotypic variance was estimated by the formula used by Johnson et al. [14]. Heritability and genetic advance were measured using the formula given by Singh and Chaudhury [15]. Genotypic and phenotypic co-efficient of variation were calculated by the formula of Burton [16]. Correlation coefficient analysis was done by the formula proposed by Miller et al. [17]. Path coefficient analysis was performed according to the method decribed by Dewey and Lu [18]. The principal component analysis (PCA), was done by using GENESTAT software program [19]. The heatmaps were created using online heatmapper tool (www2.heatmapper.ca).

\section{Results and Discussion}

\subsection{Genetic Variability}

The analysis of variance (ANOVA) revealed the existence of significant variations for days to $50 \%$ flowering, days to $80 \%$ maturity, plant height, silique length, number of seeds per silique and seed yield per plant among 35 mustard genotypes (Table 2). This suggests that there is an opportunity for the genetic improvement of the mustard for these traits. The higher phenotypic variance $\left(\sigma^{2} p\right)$ compared to the genotypic variance $\left(\sigma^{2} g\right)$ for the studied traits indicates the prevalence of environmental effect for the phenotypic expression of these traits (Table 2). The higher $\sigma^{2} g$ was found for plant height, silique length, and number of seeds per silique (Table 2). The results indicate the presence of high genetic variability for these traits. The high heritability was observed for number of primary branches per plant, number of secondary branches per plant, siliqua length, and number of siliqua per plant, number of seeds per silique, 1000-seed weight and seed yield per plant. However, siliqua length, number of siliqua per plant, number of seeds per silique, 1000-seed weight and seed yield per plant showed high heritability with high genetic advance in percentage of mean. Thus suggests that these traits under additive genetic control and selection might be effective for these traits.

The heritability estimates together with genetic advance are more authentic for selecting the leading genotype (Jonson et al., 1955). Afrin et al. [20] found low heritability with high genetic advance in percentage of mean for plant height. Khan et al. [21] found high heritability coupled with high genetic advance for number of secondary branches per plant. High heritability was reported by Aytac and Kinaci [22] while Zare and Sharafzadeh [23] found low broad sense heritability for siliqua length in rapeseed. Sadat et al. [24] reported high heritability with high genetic advance for number of siliquae per plant. High heritability for number of seeds per siliqua was observed by Yadava et al. [25]. High heritability along with considerable genetic advance in percentage of mean was reported by Afrin et al. [20] for thousand seed weight. Aytac and Kinaci [22] mentioned the high heritability and genetic advance for seed yield selection for this character would be effective. Rameeh [26] also found high heritability with high genetic advance for seed yield in B. napus. L. Rahim et al. [27] reported similar results for number of pods per plant and seed yield per plant in mungbean.

Table 2. Estimation of genetic parameters for 11 characters among 35 genotypes in mustard

\begin{tabular}{|c|c|c|c|c|c|c|c|c|c|}
\hline Traits & GMS & CV $(\%)$ & o2g & o2P & GCV & PCV & h2b & GA & GA $(\%)$ \\
\hline $50 F$ & $10.1681 * *$ & 5.63 & 1.650 & 6.867 & 3.17 & 6.46 & 24.033 & 1.297 & 3.198 \\
\hline DM & $28.6381 * *$ & 2.41 & 1.414 & 5.552 & 1.41 & 2.79 & 25.464 & 1.236 & 1.461 \\
\hline PH & $79.5323 * *$ & 7.84 & 10.478 & 58.577 & 3.66 & 8.65 & 17.887 & 2.820 & 3.188 \\
\hline LMR & 1.1775 & 10.20 & 0.253 & 0.672 & 7.91 & 12.91 & 37.573 & 0.635 & 9.994 \\
\hline NPB & 1.0015 & 11.87 & 0.288 & 0.426 & 17.08 & 20.80 & 67.446 & 0.907 & 28.892 \\
\hline NSB & 1.0860 & 18.82 & 0.303 & 0.480 & 24.57 & 30.94 & 63.046 & 0.900 & 40.184 \\
\hline NSP & 0.5371 & 3.60 & 0.154 & 0.229 & 5.15 & 6.28 & 67.185 & 0.663 & 8.695 \\
\hline SL & $788.1780 * *$ & 6.60 & 253.695 & 280.789 & 20.20 & 21.25 & 90.351 & 31.188 & 39.559 \\
\hline NSS & $54.4734 * *$ & 7.37 & 17.488 & 19.497 & 21.75 & 22.96 & 89.698 & 8.159 & 42.428 \\
\hline TSW & 1.2403 & 1.79 & 0.412 & 0.416 & 19.70 & 19.78 & 89.698 & 8.159 & 42.428 \\
\hline SYP & $9.7191 * *$ & 2.05 & 3.234 & 3.251 & 28.28 & 28.35 & 99.474 & 3.695 & 58.094 \\
\hline
\end{tabular}

GMS $=$ Genotypic mean sum of Square, $\mathrm{CV}(\%)=$ Coefficient of variation, $\sigma^{2} \mathrm{~g}=$ Genotypic variance, $\sigma^{2} \mathrm{p}=\mathrm{Phenotypic}$ variance, $50 \mathrm{~F}=\mathrm{Days}$ to $50 \%$ flowering, $\mathrm{DM}=$ Days to $80 \%$ maturity, $\mathrm{PH}=$ Plant height $(\mathrm{cm}), \mathrm{LMR}=$ Length of main raceme, $\mathrm{NPB}=\mathrm{Number}$ of primary branches per plant, NSB $=$ Number of secondary branches per plant, NSP $=$ Number of siliqua per plant, NSS $=$ Number of seed per siliqua, $S L=S i l i q u a l e n g t h$, $\mathrm{TSW}=$ Thousand seed weight $(\mathrm{g}), \mathrm{SYP}=$ Seed yield per plant, GCV $=$ Genotypic coefficient of variation and $\mathrm{PCV}=\mathrm{Phenotypic}$ coefficient of variation. 


\subsection{Association Studies}

Yield is a complex trait and controlled by polygene and very often influenced by environment. Therefore, phenotypic selection based only on yield is not effective. Correlation and path co-efficient helps the way to select plant for breeding purpose by the plant breeders.

Genotypic and phenotypic correlation coefficients among 11 characters are presented in Table 3 and Figure 1. In most instances, there was a close agreement between genetic correlations and phenotypic correlations. The genotypic correlations were higher than phenotypic correlations for the studied traits. Seed yield had a highly significant positive correlation with number of primary branches per plant, siliqua length, number of siliqua per plant, number of seeds per silique, 1000 -seed weight and seed yield per plant at both the genotypic and phenotypic level. Among these, number of siliqua per plant, 1000 -seed weight and seed yield per plant highly significant strong positive correlation with seed yield at both levels suggests the high degree of association between these traits. Nasim et al. [28] reported positive correlation between pod length and 1000- seed weight. Malik et al. [29] and Jeromela et al. [30] reported positive correlation between siliqua per plant and seed yield. Rameeh [26] reported that number of seeds per siliqua had positively correlated with seed yield per plant. Hakim [31] mentioned that yield had significant positive correlation with number of pods per plant in mungbean. As genetic correlation coefficient was higher than phenotypic correlation coefficient, it reveals that the apparent association of two characters is mainly due to genetic effects.

The direct and indirect effects of yield contributing traits on seed yield were analyzed by path analysis. Seed yield per plant was considered as effect (dependent variable) while remaining traits were treated as causes (independent variables) and shown in Table 4. The results showed that number of siliqua per plant had maximum direct effect followed by number of seeds per siliqua on seed yield. Number of siliqua per plant had a positive indirect effect to all the traits and finally this trait had a highly significant positive genotypic correlation with yield per plant. Similarly, number of seeds per siliqua had a positive indirect via most of the traits except for days to $50 \%$ flowering, showed a positive correlation with seed yield per plant. These results indicate the correlation is mainly due to the direct effect of a character and it was realized via indirect positive and negative effects. It reveals the true relationship between them and direct selection for this trait will be rewarding for the genetic improvement of yield. Sharafi et al. [32] found the number of siliqua per plant had the highest direct effect on seed yield. They also reported that number of seeds per siliqua had direct positive effect on yield per plant. On the contrary, a negative direct effect for seeds per siliqua on seed yield per plant has been reported by Basalma [33]. The value of residual effect was 0.211 . It indicated that beside the component characters, there was an influence of some other attributes (approx. $21.1 \%$ ) on seed yield.

Table 3. Genotypic $\left(r_{g}\right)$ and phenotype $\left(r_{p}\right)$ correlation coefficients among different pairs of yield and yield contributing characters for different genotype of mustard

\begin{tabular}{|c|c|c|c|c|c|c|c|c|c|c|c|}
\hline Traits & & DM & $\mathrm{PH}$ & LMR & NPB & NSB & SL & NSP & NSS & TSW & SYP \\
\hline \multirow{2}{*}{$50 \mathrm{~F}$} & $r_{g}$ & $0.9086^{* *}$ & $-0.699 * *$ & 0.2882 & 0.2196 & -0.2006 & 0.1297 & -0.1106 & 0.0765 & -0.1296 & -0.2101 \\
\hline & $r_{p}$ & $0.899 * *$ & -0.2857 & 0.1186 & 0.1022 & -0.1382 & 0.0364 & -0.0645 & 0.065 & -0.0925 & -0.153 \\
\hline \multirow{2}{*}{ DM } & $r_{g}$ & & $-0.4506^{* *}$ & $0.3861^{*}$ & 0.1357 & -0.3238 & 0.0968 & -0.1666 & 0.1561 & -0.0563 & -0.1599 \\
\hline & $r_{p}$ & & -0.2672 & 0.1288 & 0.0669 & -0.2195 & 0.0303 & -0.0998 & 0.1249 & -0.0404 & -0.1213 \\
\hline \multirow{2}{*}{$\mathrm{PH}$} & $r_{g}$ & & & 0.241 & -0.0604 & -0.035 & 0.2399 & 0.1057 & 0.0762 & 0.22 & 0.2484 \\
\hline & $r_{p}$ & & & 0.2209 & -0.0708 & -0.007 & 0.1443 & 0.0689 & 0.0241 & 0.1348 & 0.1545 \\
\hline \multirow{2}{*}{ LMR } & $\mathrm{r}_{\mathrm{g}}$ & & & & 0.1072 & -0.3068 & $0.3697^{*}$ & 0.0288 & 0.0473 & 0.0142 & -0.0592 \\
\hline & $r_{p}$ & & & & 0.0641 & -0.2041 & 0.2454 & 0.0058 & 0.0194 & 0.0035 & -0.0465 \\
\hline \multirow{2}{*}{ NPB } & $r_{g}$ & & & & & $-0.3373^{*}$ & $0.5153^{* *}$ & $0.7626^{* *}$ & $0.491 * *$ & $0.7858 * *$ & $0.7067 * *$ \\
\hline & $r_{p}$ & & & & & -0.2479 & $0.4473 * *$ & $0.6941^{* *}$ & $0.478 * *$ & $0.7296 * *$ & $0.6579 * *$ \\
\hline \multirow{2}{*}{ NSB } & $r_{g}$ & & & & & & $-0.5432 * *$ & -0.3322 & -0.1738 & -0.1249 & -0.1871 \\
\hline & $r_{p}$ & & & & & & $-0.4734 * *$ & -0.2895 & -0.1441 & -0.1183 & -0.1711 \\
\hline \multirow{2}{*}{ SL } & $\mathrm{r}_{\mathrm{g}}$ & & & & & & & $0.5144^{* *} *$ & 0.3202 & $0.3477 *$ & $0.3791^{*}$ \\
\hline & $r_{p}$ & & & & & & & $0.464 * *$ & 0.2859 & 0.3262 & $0.3551^{*}$ \\
\hline \multirow{2}{*}{ NSP } & $r_{g}$ & & & & & & & & $0.6719 * *$ & $0.8481 * *$ & $0.8643^{* *}$ \\
\hline & $r_{p}$ & & & & & & & & $0.6512 * *$ & $0.8324 * *$ & $0.8493 * *$ \\
\hline \multirow{2}{*}{ NSS } & $r_{g}$ & & & & & & & & & $0.6898 * *$ & $0.7705^{* *}$ \\
\hline & $r_{p}$ & & & & & & & & & $0.6771 * *$ & $0.7568 * *$ \\
\hline \multirow{2}{*}{ TSW } & $r_{g}$ & & & & & & & & & & $0.9448 * *$ \\
\hline & $r_{p}$ & & & & & & & & & & $0.9426^{* *}$ \\
\hline
\end{tabular}

$* *=$ Significant at $1 \% ; *$ Significant at $5 \%$.

$50 \mathrm{~F}=$ Days to $50 \%$ flowering, $\mathrm{DM}=$ Days to $80 \%$ maturity, $\mathrm{PH}=$ Plant height $(\mathrm{cm}), \mathrm{LMR}=$ Length of main raceme, $\mathrm{NPB}=\mathrm{Number}$ of primary branches per plant, $\mathrm{NSB}=$ Number of secondary branches per plant, $\mathrm{NSP}=$ Number of siliqua per plant, $\mathrm{NSS}=\mathrm{Number}$ of $\mathrm{seed}$ per siliqua, $\mathrm{SL}=$ Siliqua length, $\mathrm{TSW}=$ Thousand seed weight $(\mathrm{g})$ and $\mathrm{SYP}=$ Seed yield per plant 


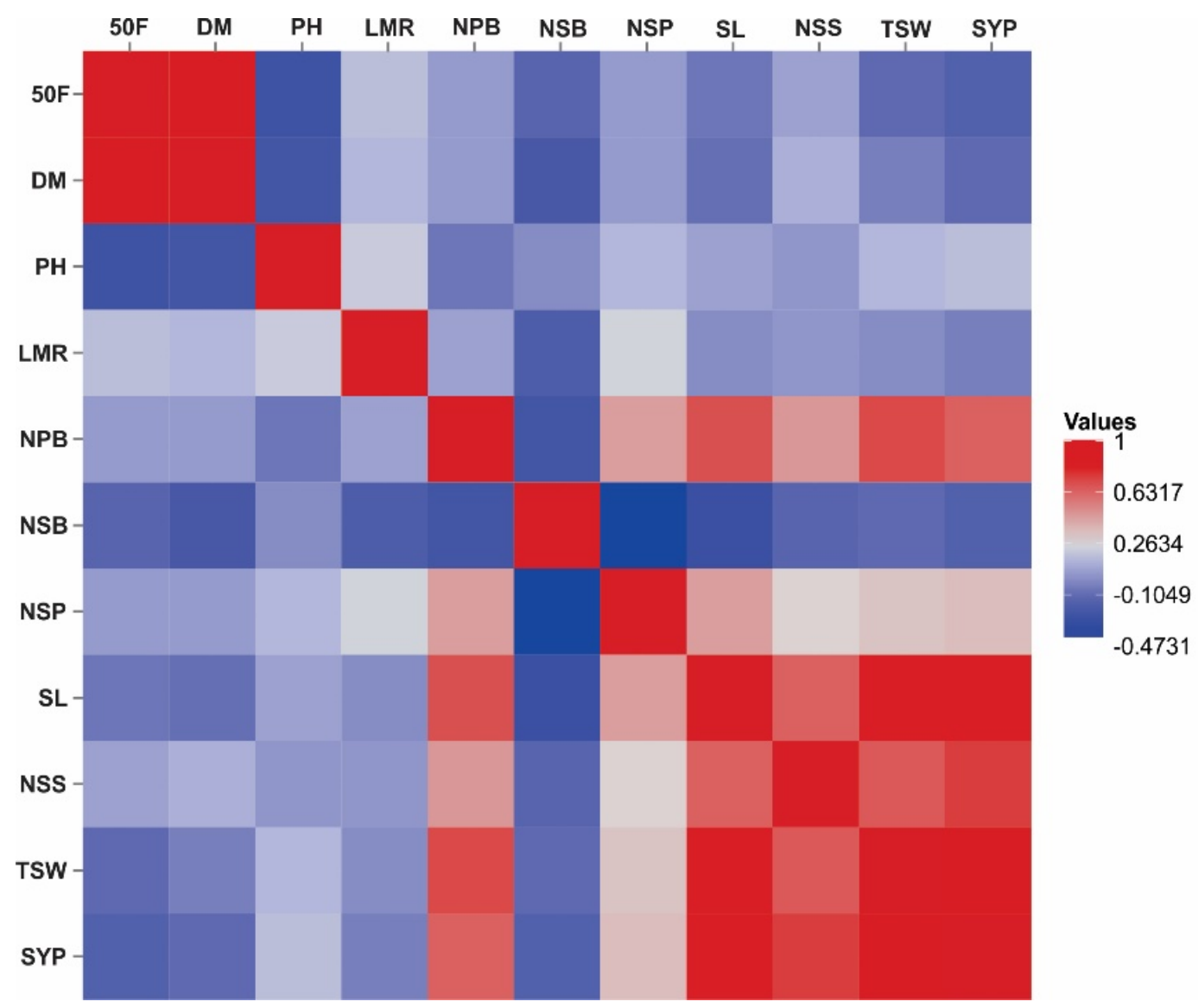

Figure 1. Correlation matrix showing correlation between different traits of mustard. The red and blues colors in the legend indicates highest and lowest values, respectively. $50 \mathrm{~F}=$ Days to $50 \%$ flowering, $\mathrm{DM}=$ Days to $80 \%$ maturity, $\mathrm{PH}=$ Plant height $(\mathrm{cm})$, LMR= Length of main

Table 4. Path coefficient analysis showing direct and indirect effects of different characters on yield of mustard

\begin{tabular}{|c|c|c|c|c|c|c|c|c|c|c|c|c|}
\hline \multirow{2}{*}{ Traits } & \multirow{2}{*}{$\begin{array}{l}\text { Direct } \\
\text { effect }\end{array}$} & \multicolumn{10}{|c|}{ Indirect effect } & \multirow{2}{*}{$\begin{array}{c}\mathrm{r}_{\mathrm{g}} \\
\text { with } \\
\text { Yield }\end{array}$} \\
\hline & & $50 \mathrm{~F}$ & $\mathrm{DM}$ & $\mathrm{PH}$ & LMR & NPB & NSB & SL & NSP & NSS & TSW & \\
\hline $50 \mathrm{~F}$ & -0.171 & & 0.021 & -0.014 & -0.010 & -0.010 & -0.010 & -0.010 & -0.015 & 0.016 & -0.008 & -0.210 \\
\hline $\mathrm{DM}$ & 0.028 & -0.152 & & -0.017 & -0.005 & -0.007 & -0.006 & -0.007 & -0.022 & 0.033 & -0.004 & -0.160 \\
\hline $\mathrm{PH}$ & 0.102 & 0.023 & 0.011 & & 0.008 & 0.005 & 0.015 & 0.015 & 0.046 & 0.011 & 0.014 & 0.248 \\
\hline LMR & -0.040 & -0.001 & -0.005 & 0.014 & & -0.001 & -0.002 & -0.003 & -0.013 & -0.010 & 0.003 & -0.059 \\
\hline NPB & 0.124 & 0.013 & 0.013 & 0.005 & 0.012 & & 0.013 & 0.012 & 0.317 & 0.181 & 0.018 & $0.707 * *$ \\
\hline NSB & -0.008 & 0.012 & -0.009 & -0.004 & 0.000 & -0.018 & & -0.003 & -0.122 & -0.040 & 0.004 & -0.187 \\
\hline SL & 0.003 & 0.012 & 0.005 & 0.014 & 0.001 & 0.045 & 0.008 & & 0.207 & 0.090 & -0.006 & $0.379 *$ \\
\hline NSP & 0.520 & 0.006 & 0.003 & 0.010 & 0.005 & 0.070 & 0.005 & 0.003 & & 0.227 & 0.014 & $0.864 * *$ \\
\hline NSS & 0.369 & -0.007 & 0.008 & 0.003 & 0.005 & 0.055 & 0.004 & 0.003 & 0.319 & & 0.011 & $0.771 * *$ \\
\hline TSW & 0.050 & 0.119 & 0.111 & 0.114 & 0.116 & 0.102 & 0.113 & 0.112 & 0.035 & 0.072 & & $0.945^{* *}$ \\
\hline
\end{tabular}

Residual Effect $=0.211$

**, * indicates significant at the 0.01 and 0.05 level, respectively. $50 \mathrm{~F}=$ Days to $50 \%$ flowering, $\mathrm{DM}=$ Days to $80 \%$ Maturity, $50 \mathrm{~F}=\mathrm{Days}$ to $50 \%$ flowering, $\mathrm{DM}=$ Days to $80 \%$ maturity, $\mathrm{PH}=$ Plant height $(\mathrm{cm}), \mathrm{LMR}=$ Length of main raceme, $\mathrm{NPB}=$ Number of primary branches per plant, $\mathrm{NSB}=$ Number of secondary branches per plant, $\mathrm{NSP}=$ Number of siliqua per plant, $\mathrm{NSS}=$ Number of seed per siliqua, $\mathrm{SL}=\mathrm{Siliqua}$ length and TSW $=$ Thousand seed weight $(\mathrm{g})$. 


\subsection{Selection of Elite Genotypes}

We further performed principal component analysis with 35 mustard genotypes for 11 yield and its component traits. The results showed eigen values of principal component axes of coordination of genotypes with the first axes totally accounted for the variation among the genotypes (38.75). These three principal components account for $71.84 \%$ of the total variation (Table 5). Zaman et al. [34] reported that first three axes accounted for $94.00 \%$ of the total variation whereas the first principal components accounted for $81.94 \%$. We performed a cluster analysis using 35 mustard genotypes in respect of 11 traits using online tool (http://www2.heatmapper.ca). The result showed that 35 mustard genotypes were into four clusters (Table 5 and Figure 2). The maximum 12 genotypes were included in cluster III while only four for cluster IV (Table 6). The genotypes belong to cluster IV (G10, G24, G30 and G33) showed better performance for number of primary branches per plant, number of silique per plant, siliqua length, number of seeds per silique, 1000-seed weight and seed yield per plant (Figure 2). Among the genotypes of cluster IV, G24 had highest mean values for number of primary branches per plant, number of silique per plant, siliqua length, and seed yield per plant among all 35 mustard genotypes (Figure 2). Furthermore, the genotypes of cluster IV were distantly related among other clusters (Figure 3). The genetically diverse parent selection is one of the key activities for a successful hybridization program [35].

Table 5. Eigen values and yield percent contribution of 11 characters of 35 genotypes of mustard

\begin{tabular}{|c|c|c|c|}
\hline Traits & $\begin{array}{c}\text { Eigen } \\
\text { values }\end{array}$ & $\begin{array}{c}\text { Percent } \\
\text { variation }\end{array}$ & $\begin{array}{c}\text { Cumulative \% of } \\
\text { percent variation }\end{array}$ \\
\hline $50 \mathrm{~F}$ & 4.262 & 38.75 & 38.75 \\
\hline DM & 2.207 & 20.06 & 58.81 \\
\hline PH & 1.434 & 13.03 & 71.84 \\
\hline LMR & 0.959 & 8.71 & 80.55 \\
\hline NPB & 0.669 & 6.08 & 86.63 \\
\hline NSB & 0.514 & 4.68 & 91.31 \\
\hline SL & 0.445 & 4.04 & 95.35 \\
\hline NSP & 0.236 & 2.15 & 97.50 \\
\hline NSS & 0.172 & 1.57 & 99.07 \\
\hline TSW & 0.072 & 0.66 & 99.73 \\
\hline SYP & 0.029 & 0.27 & 100.00 \\
\hline
\end{tabular}

Table 6. Distribution of genotypes in different clusters

\begin{tabular}{|c|c|c|}
\hline Cluster & $\begin{array}{c}\text { Number of } \\
\text { population }\end{array}$ & Genotypes \\
\hline I & 9 & $\begin{array}{c}\text { G1, G3, G7, G9, G11, G13, G14, } \\
\text { G16 and G29 }\end{array}$ \\
\hline II & 10 & $\begin{array}{c}\text { G2, G4, G15, G17, 18, G20, G26, } \\
\text { G32, G34 and G35 }\end{array}$ \\
\hline III & 12 & $\begin{array}{c}\text { G5, G6, G8, G12, G19, G21, G22, } \\
\text { G23, G25, G27, G28 and G31 }\end{array}$ \\
\hline IV & 4 & G10, G24, G30 and G33 \\
\hline
\end{tabular}

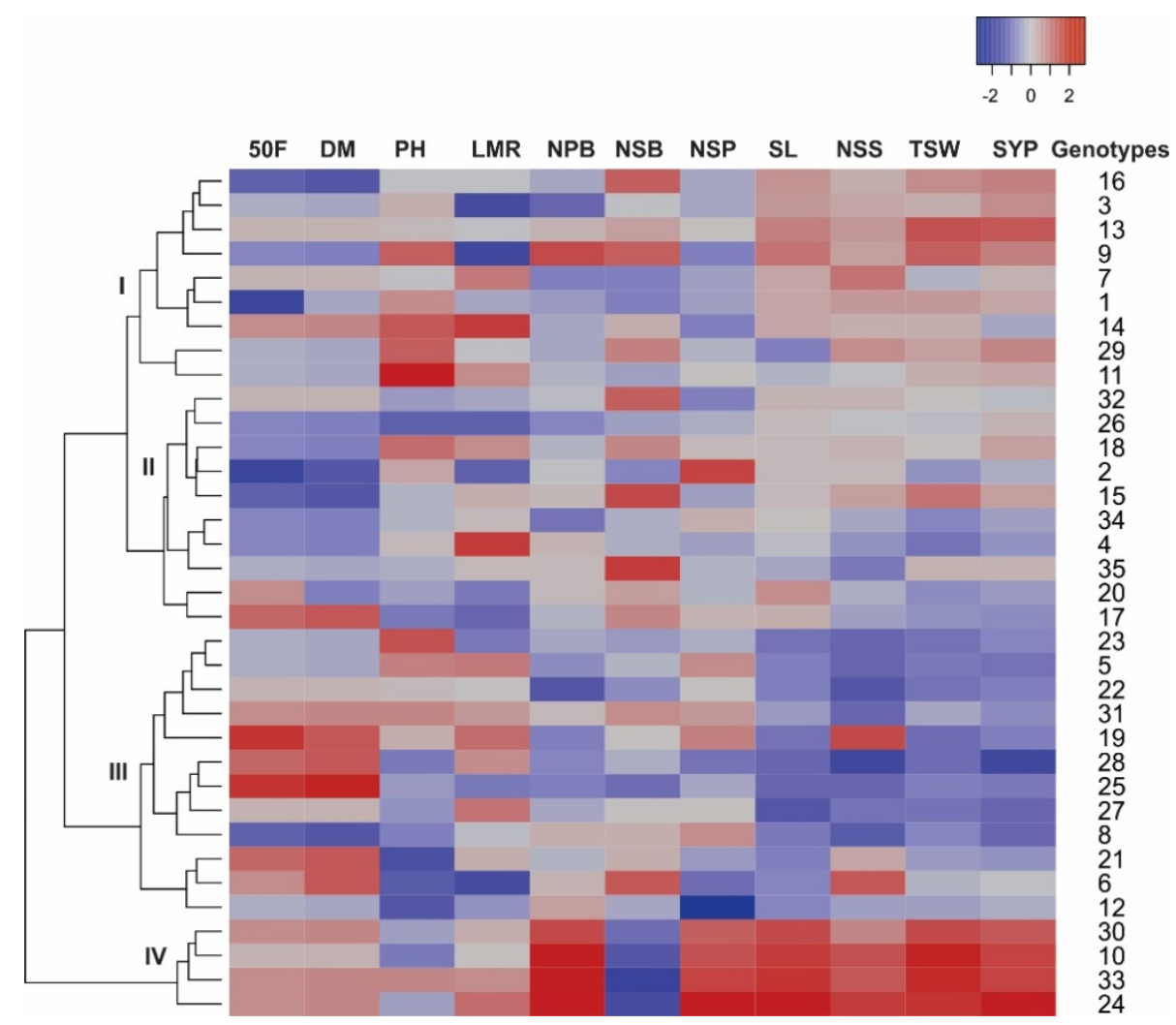

Figure 2. Heatmap representation of 35 mustard genotypes into four clusters in respect of 11 traits. The red and blues colors in the legend indicates highest and lowest values, respectively. $50 \mathrm{~F}=$ Days to $50 \%$ flowering, $\mathrm{DM}=$ Days to $80 \%$ maturity, $\mathrm{PH}=\mathrm{Plant}$ height $(\mathrm{cm})$, LMR= Length of main raceme, $\mathrm{NPB}=$ Number of primary branches per plant, $\mathrm{NSB}=$ Number of secondary branches per plant, $\mathrm{NSP}=\mathrm{Number}$ of siliqua per plant, $\mathrm{NSS}=$ Number of seed per siliqua, $\mathrm{SL}=$ Siliqua length, $\mathrm{TSW}=$ Thousand seed weight $(\mathrm{g})$ and $\mathrm{SYP}=$ Seed yield per plant 


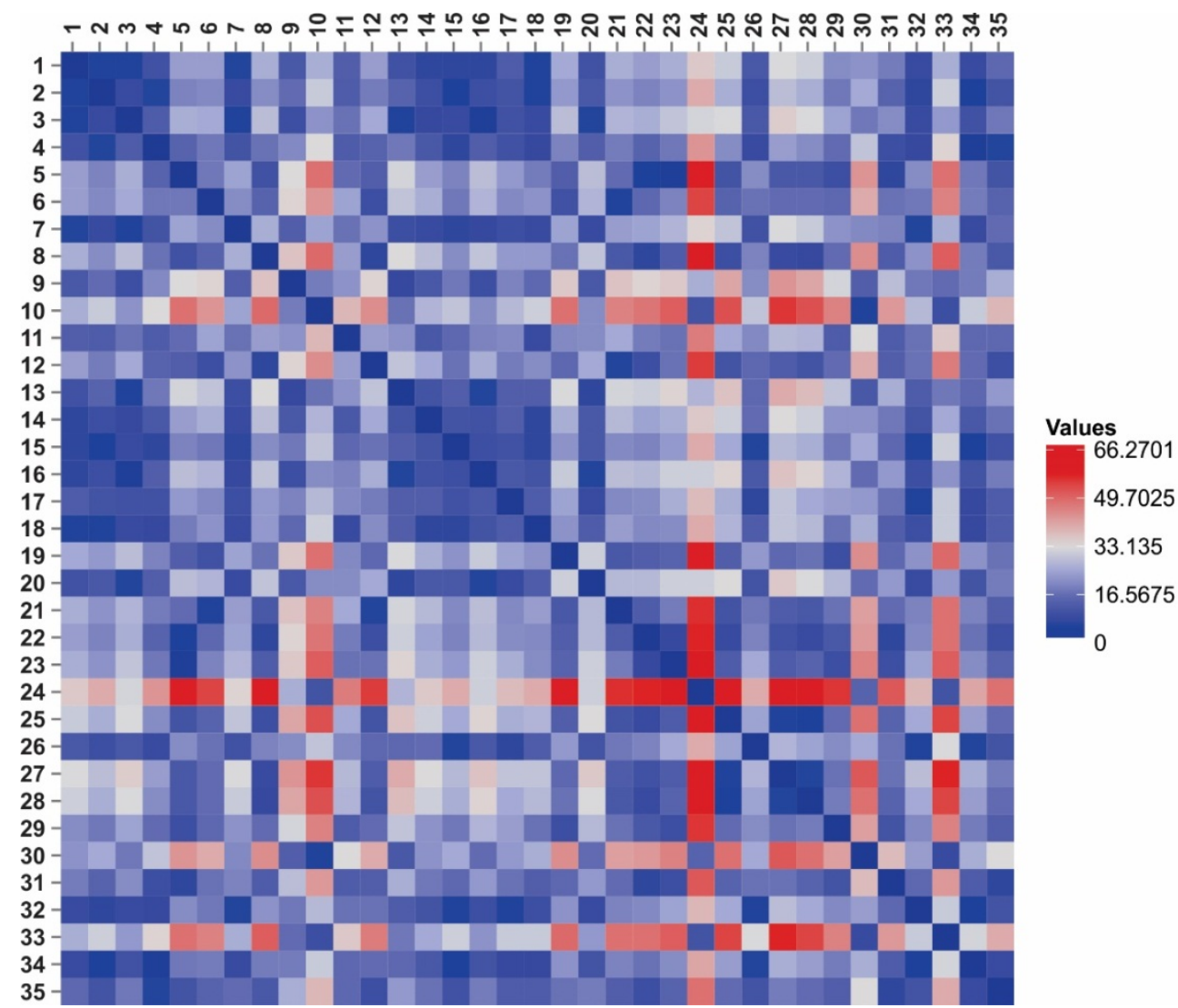

Figure 3. Distance matrix represents the pairwise comparisons between mustard genotypes in respect of 11 traits. The red and blues colors in the legend indicates highest and lowest values, respectively. $50 \mathrm{~F}=$ Days to $50 \%$ flowering, $\mathrm{DM}=$ Days to $80 \%$ maturity, $\mathrm{PH}=\mathrm{Plant}$ height $(\mathrm{cm}), \mathrm{LMR}=$ Length of main raceme, $\mathrm{NPB}=$ Number of primary branches per plant, $\mathrm{NSB}=$ Number of secondary branches per plant, $\mathrm{NSP}=\mathrm{Number}$ of siliqua per plant, $\mathrm{NSS}=$ Number of seed per siliqua, $\mathrm{SL}=$ Siliqua length, $\mathrm{TSW}=$ Thousand seed weight $(\mathrm{g})$ and $\mathrm{SYP}=$ Seed yield per plant

\section{Conclusions}

Considering genetic parameters, interrelationships among major yield contributing traits, agronomic performance, genotypic distance, it can be concluded that the genotype belong to the cluster II and IV might product high heterosis. Therefore, genotypes G23, G5, G22 and G24 could be recommended for future hybridization program to develop new cultivars with higher yield and other agronomic performance.

\section{Acknowledgements}

We thank SAURES, Shere-Bangla Agricultural University (SAU), Dhaka-1207, and Bangladesh for providing experimental field and other supports for successful completion of the research.

\section{REFERENCES}

[1] Abraham V. Rate of out-crossing in Indian mustard, Brassica juncea. Cruciferae Newsl. 1994; 16: 69-70.
[2] Rakow G, Woods, DL. Outcrossing in rape and mustard under Saskatchewan prairies conditions. Canadian J. Plant Sci. 1987; 67: 147-151.

[3] Ram HH, Hari GS. Crop Breeding and Genetics. Kalyani Publishers, New Delhi-110002, 1998; p381.

[4] Yarnell SH, Rai B, Singh B. Component analysis of harvest index in Brassica oilseeds. Indian J Agric Res. 1956; 20(3): 129-134.

[5] Kimber DS, McGregor DI. The species and their origin, cultivation and world production. In: Kimber D. and McGregor D.I. (eds.), Brassica Oilseeds: Production and Utilization. CABI Publishing, Wallingford, UK, 1995; pp. $1-9$.

[6] FAO (Food and Agriculture Organization). Production Year Book. Food and Agriculture Organization of the United Nations, Rome. Italy. 2012; www.fao.org

[7] Ahmed M. Results of farm level socio-economic study on mustard production. Bangladesh J. Agril. Res. 2008; 13(1): 20-23.

[8] BBS (Bangladesh Bureau of Statistics). Statistical Yearbook of Bangladesh. Bangladesh Bureau of Statistics, Stat. Div., Ministry Planning, Govt. Peoples Rep. Bangladesh, Dhaka. 2015 ; p.477.

[9] Begum F, Hossain F, Mondal MRI. Influence of Sulphur on morpho-physiological and yield parameters of rapeseed. 
Bangladsh J. Agril. Res. 2012; 37(4): 645-652.

[10] Rahman MM. Status of oil seeds and future prospects in Bangladesh, Paper Presented in Review Workshop on the Impact of Technology Transfer on Oil Crops, held at BARI on 29 April 2002.

[11] BBS (Bangladesh Bureau of Statistics). Bangladesh Bureau of Statistics. Monthly Statistical Bulletin of Bangladesh. January, Statistics Div., Ministry of Planning, Govt. People's Repub. Bangladesh. 2012; p.46.

[12] FAO (Food and Agriculture Organization of the United Nations). Agricultural production year book. 2013; http://faostat.fao.org.

[13] AIS (Agricultural Information Service). Krishi Diary (In Bangla). Agril Inform Ser Khamarbari, Farmgate, Dhaka, Bangladesh, 2013; p.16.

[14] Johnson HW, Robinson HF, Comstoc R. Estimates of genetic and environmental variability in soybeans. Agron. J. 1955; 47: 314-318.

[15] Singh RK, Chaudhary BD. Biometrical methods in quantitative genetic analysis. Kalyani Publishers, New Delhi, India. 1985; p.56.

[16] Burton GW. Quantitative inheritance in grass pea. Proc. of the $6^{\text {th }}$ Int. Grassland Cong. Pennsylvania, USA. 1952; pp. 277-283.

[17] Miller PA, Williams JC, Robinson HF, Comstock RE. Estimates of genotypic and environmental variances and covariances in upland cotton and their implications in selection. Agron. J. 1958; 50: 126-131.

[18] Dewey DR, Lu K. A correlation and path-coefficient analysis of components of crested wheatgrass seed production. Agron. J. 1959; 51: 515-518.

[19] Digby P, Galway M, Lane P. GENSTAT5. A second course. Oxford Science Publications, Oxford. 1989; pp. 103-108.

[20] Afrin KS, Mahmud F, Bhuiyan MSR, Rahim MA. Assessment of genetic variation among advanced lines of Brassica napus L. Agronomski Glasnik. 2011; 4(5): 201-225.

[21] Khan RSA, Khan FA. Evaluation of genetic potential of some Brassica germplasm collections. Int. J. of Agric. and Bio. 2003; 6(4): 30-31.

[22] Aytac Z, Kinaci G. Genetic variability and association studies of some quantitative characters in winter rape seed (Brassica napus L.). African J. Biotech. 2009; 8(15): 3547-3554.

[23] Zare M, Sharafzadeh S. Genetic variability of some rapeseed (Brassica napus L.) cultivars in Southern Iran. African J. Agric. Res. 2012; 7(2): 224-229.

[24] Sadat HA, Nematzadeh GA, Jelodar NB, Chapi OG. Genetic evaluation of yield and yield components at advanced generations in rapeseed (Brassica napus L.). African J. Agric. Res. 2010; 5(15): 1958-1964.

[25] Yadava YP, Singh H, Singh, D. Gene action for seed yield and its attributes under research. Indian J. Genet. Plant Breeding. 1993; 6(1): 168-172.

[26] Rameeh V. Heritability, genetic variability and correlation analysis of some important agronomic traits in rapeseed advanced lines. Cercetari Agronomice in Moldova. 2015; 48(4): 71-80.

[27] Rahim MA, Mia AA, Mahmud F, Zeba N, Afrin KS. genetic variability, character association and genetic divergence in mungbean (Vigna radiate L. Wilczek). Plant Omics. 2010; 3: $1-6$.

[28] Nasim A, Ferhatullah, Iqbal S, Shah S, Azam SM. Genetic variability and correlation studies for morpho-physiological traits in Brassica napus L. Pakistan J. Bot. 2013; 45(4): 1229-1234.

[29] Malik MA, Khan AS, Khan MAS, Khan BR, Mohamand AS. Study of correlation among morphological parameters in different varieties/accessions of Brassica species. Pakistan J. Biol. Sci. 2000; 3(7): 1180-1182.

[30] Jeromela MA, Marinkovic R, Mijic A, Zdunic MZ. Interrelation between oil yield and other quantitative traits in rapeseed (Brassica napus L.). Sci. J. Agri. 2007; 8(2): 165-170.

[31] Hakim L. Variability and correlation of agronomic characters of mungbean germplasm and their utilization for variety improvement program. Indonesian J. Agril. Sci. 2008; 9: 24-28

[32] Sharafi Y, Majidi MM, Jafarzadeh M, Mirlohi A. Multivariate analysis of genetic variation in winter rapeseed (Brassica napus L.) cultivars. Journal of Agricultural Science and Technology. 2015; 17(5): 1319-1331.

[33] Basalma D. The correlation and path analysis of yield and yield components of different winter rapeseed (Brassica napus ssp. oleifera L.) cultivars. Res. J. of Agric. Bio. Sci. 2008; 4(2): 120-125.

[34] Zaman MA, Tuhina-Khatun M, Ullah MZ, Moniruzzamn M, Rahman MZ. Multivariate analysis of divergence in Advanced Lines of mustard (Brassica spp). Bangladesh J. Pl. Breed. Genet. 2010; 23(2): 29-34.

[35] Afrin KS, Mahmud F, Bhuiyan MSR, Rahim MA. Genetic Divergence in Advanced Lines of Oilseed Rape (Brassica napus ssp oleifera L.). Agriculturae Conspectus Scientificus. 2012; 77(2): 81-85. 